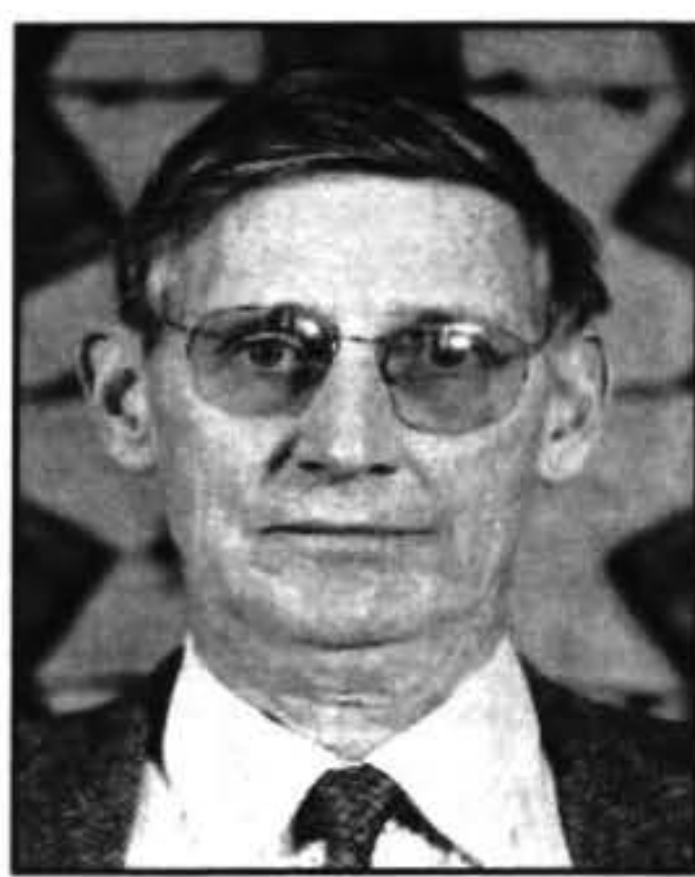

Policy Coordination and Development Section

\section{AGING: A SYNOPTIC \\ VIEW OF \\ SOME ECONOMIC IMPLICATIONS}

\author{
The Treasury \\ Grant Scobie ${ }^{1}$ \\ The Treasury
}

\begin{abstract}
Significant shifts in the age structure of the New Zealand population are underway. Their principal effect will be felt between 2020 and 2040. The paper documents these changes and compares them with other OECD countries. There will be widespread implications for savings, investment, the current account balance, productivity, the labour market, growth of the economy and public expenditures. The paper provides a brief sketch of each of these areas. Behavioural response parameters estimated from historical data may offer little guide to the future, which will involve age dependency ratios well outside the range previously experienced. Global capital markets will play an important role in the intergenerational transfer of resources.
\end{abstract}

Key Words: Aging, New Zealand, demographics, fiscal effects, macroeconomics.

Across a wide range of countries, populations are aging. Typically, the next two or three decades will see accelerated changes. These phenomena are especially marked in the OECD countries. New Zealand is no exception.

The implications of these changes are potentially very significant, but generally not well understood. The changes will have wide-ranging consequences, for individuals, governments and nations - in fact for the entire global economic system. The effects will be complex and pervasive with ramifications throughout society. It is hardly surprising to find we lack the analytical apparatus to forecast the impact in fifty years of changes without historical precedent.

In this paper I make no such forecasts. Rather, I attempt to build on our understanding of how economic forces work, in order to provide a framework for assessing the implications of aging for the economy. I confine my attention to a traditional set of issues found in the economist's toolkit - saving, investment, the capital stock, interest rates, the current account, public expenditure and the labour market.

Section 2 of the paper provides a few salient projections to highlight the key aspects of demographic change. In section 3 I consider the macroeconomic implications for the domestic economy, while I broaden the focus to the global economy in section 4 . I then turn to the labour market implications in section 5 , before looking at the possible effect on the level and composition of public spending (section 6). Conclusions are in Section 7.

\section{Demographic Changes}

The forecasts for the population and its age structure have been well documented and only salient features will be summarised here. As a general rule, the Series 4 projections (Statistics New Zealand, 2000) have been used in this paper (medium fertility and mortality rates with the long term net migration level set at 5,000).

Of particular interest are the changes in the dependency ratio. Dependency ratios are a convenient way to summarise the changes in the population age structure. They are typically calculated as the number aged $65+$ as a share of the working aged population (15-64), or the number of young persons (0-14) again as a share, or the combined (total) dependency ratio. What have been the historical paths of these ratios in New Zealand and how are they projected to change in the future? How do the patterns in New Zealand compare to those of other OECD countries?

Table 1 provides the basic data for the three key age groups, while Table 2 presents the ratios. Figure 1 plots the young and old dependency ratios. The young ratio has fallen markedly since its peak in 1961 and over the next 100 years remains essentially constant after 2021 . In contrast, the old age dependency ratio, whose increase to date has been modest starts to climb sharply for three decades following 2011 and then grows modestly until the end of the current century.

Clearly these ratios are tending to offset each other. Figure 2 shows the total (young + old) dependency ratio for two centuries. It is expected that the total ratio will reach 
Table 1. Projected Age Structure of the New Zealand Population:1901-2101

\begin{tabular}{ccccc}
\hline Year & $\mathbf{0 - 1 4}$ & $\begin{array}{c}\text { Population } \\
\mathbf{1 5 - 6 4}\end{array}$ & $\mathbf{( ' 0 0 0 )}$ & 65+ \\
\hline 1901 & 256 & 517 & 31 & 2,188 \\
1951 & 571 & 1,191 & 178 & 2,700 \\
1961 & 799 & 1,407 & 209 & 2,969 \\
1971 & 910 & 1,709 & 244 & 3,125 \\
1981 & 849 & 2,011 & 316 & 3,146 \\
1991 & 788 & 2,258 & 389 & 3,168 \\
2001 & 878 & 2,526 & 457 & 3,336 \\
2011 & 812 & 2,760 & 566 & 3,389 \\
2021 & 775 & 2,819 & 781 & 3,577 \\
2031 & 795 & 2,739 & 1,031 & 3,857 \\
2041 & 763 & 2,709 & 1,170 & 3,974 \\
2051 & 737 & 2,712 & 1,181 & 3,969 \\
2061 & 737 & 2,618 & 1,221 & 4,019 \\
2101 & 674 & 2,413 & 1,152 & 3,927 \\
\hline
\end{tabular}

Source: Statistics New Zealand (2000); Series 4 projection

its lowest level by 2011, and is then projected to rise substantially. Two series are shown. Consider first the unadjusted series based on raw head counts. If the dependency ratio is interpreted as a measure of the share of the population whose consumption must be supported from the output of the working age population, then it is of note that the total "burden" only reaches its former 1961 peak in 2041. In short, despite the rise in the older population, the unadjusted ratio is offset by falls in the young age group so that from now until 2041 the total burden would be no higher than it had been in the past.

However this assumes implicitly that the consumption requirements are uniform across all age groups. If an allowance is made for the relative consumption levels of the different age groups, an adjusted dependency ratio can be constructed. As seen in Figure 2, this ratio is currently reaching a low point, but then rises more sharply than the unadjusted series and ends modestly above the unadjusted level. It is still the case that it will take more than 20 years before the adjusted dependency reaches it former peak. While dependency ratios are undoubtedly set to increase, they are projected to remain within the bounds of historical experience for at least another 20 years.

Comparisons with selected OECD countries are given in Tables 3 and 4. Comparisons with other OECD countries as a group and for Australia are shown for the age (Figure 3 ) and total (Figure 4) dependency ratios. Figure 5 indicates that New Zealand's age dependency ratio, starting from a lower base, will rise by more than the OECD average over the next half century. The increases in the total dependency ratio for New Zealand are however, more closely aligned to those for the OECD (Figure 6).

Table 2. Dependency Ratios: New Zealand: 1901-2101

\begin{tabular}{lccccccc}
\hline & & & \multicolumn{3}{c}{ Dependency Ratios } & & \\
& $\mathbf{O} / \mathbf{W}$ & $\mathbf{W} / \mathbf{O}$ & $\mathbf{Y} / \mathbf{O}$ & $\mathbf{Y} / \mathbf{W}$ & $(\mathbf{O}+\mathbf{Y}) / \mathbf{W}$ & $\mathbf{W} /(\mathbf{O}+\mathbf{Y})$ & $(\mathbf{O}+\mathbf{Y}) /$ Total \\
\hline 1901 & 0.06 & 16.68 & 8.26 & 0.50 & 0.56 & 1.80 & $\mathbf{0 . 3 6}$ \\
1951 & 0.15 & 6.69 & 3.21 & 0.48 & 0.63 & 1.59 & $\mathbf{0 . 3 9}$ \\
1961 & 0.15 & 6.73 & 3.82 & 0.57 & 0.72 & 1.40 & $\mathbf{0 . 4 2}$ \\
1971 & 0.14 & 7.00 & 3.73 & 0.53 & 0.68 & 1.48 & $\mathbf{0 . 4 0}$ \\
1981 & 0.16 & 6.36 & 2.69 & 0.42 & 0.58 & 1.73 & $\mathbf{0 . 3 7}$ \\
1991 & 0.17 & 5.80 & 2.03 & 0.35 & 0.52 & 1.92 & $\mathbf{0 . 3 4}$ \\
2001 & 0.18 & 5.53 & 1.92 & 0.35 & 0.53 & 1.89 & $\mathbf{0 . 3 5}$ \\
2011 & 0.21 & 4.88 & 1.43 & 0.29 & 0.50 & 2.00 & $\mathbf{0 . 3 3}$ \\
2021 & 0.28 & 3.61 & 0.99 & 0.27 & 0.55 & 1.81 & $\mathbf{0 . 3 6}$ \\
2031 & 0.38 & 2.66 & 0.77 & 0.29 & 0.67 & 1.50 & $\mathbf{0 . 4 0}$ \\
2041 & 0.43 & 2.32 & 0.65 & 0.28 & 0.71 & 1.40 & $\mathbf{0 . 4 2}$ \\
2051 & 0.44 & 2.30 & 0.62 & 0.27 & 0.71 & 1.41 & $\mathbf{0 . 4 1}$ \\
2061 & 0.47 & 2.14 & 0.60 & 0.28 & 0.75 & 1.34 & $\mathbf{0 . 4 3}$ \\
2101 & 0.48 & 2.09 & 0.59 & 0.28 & 0.76 & 1.32 & $\mathbf{0 . 4 3}$ \\
\hline
\end{tabular}


Figure 1. Young and Old Dependency Ratios: New Zealand: 1901-2101

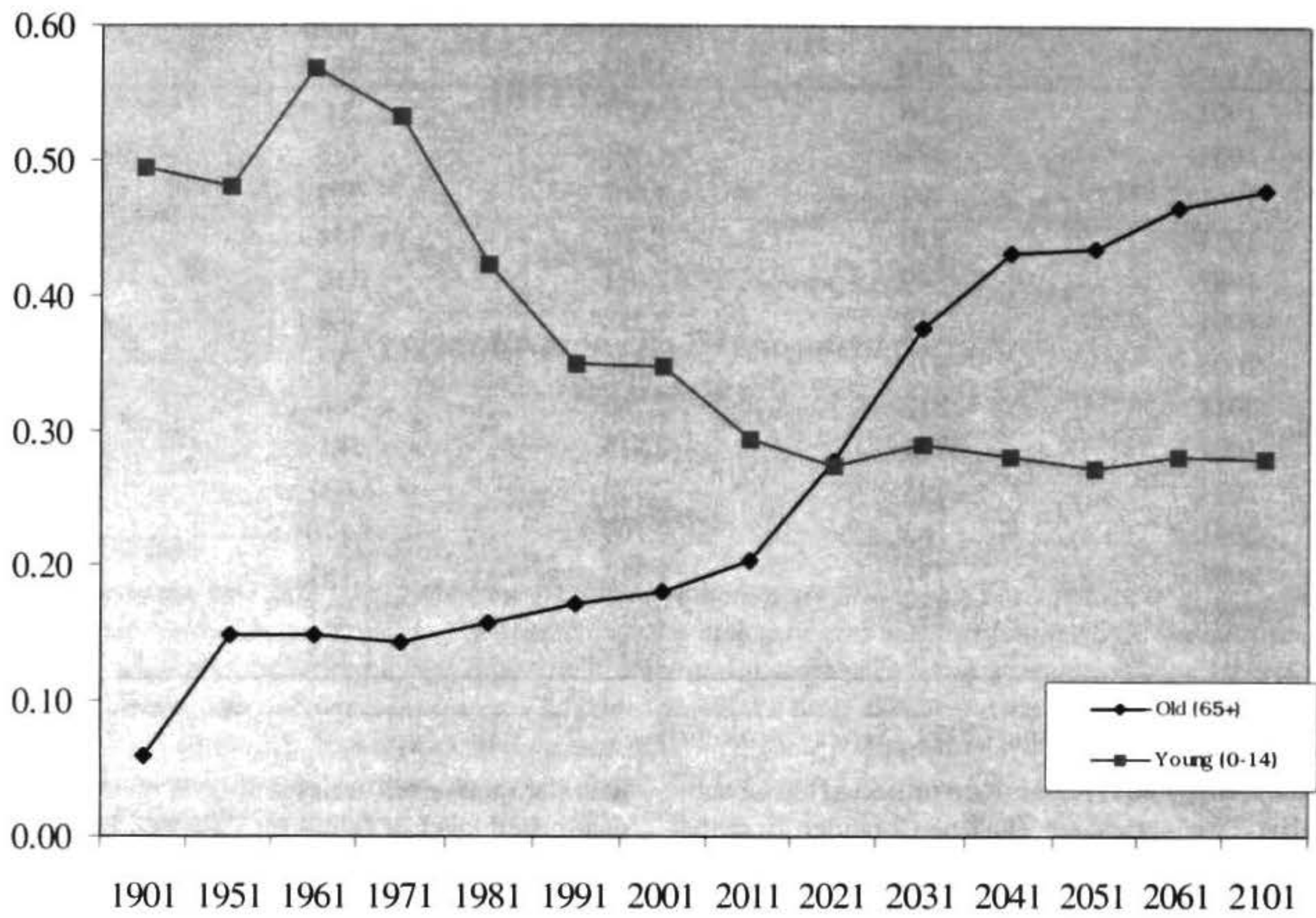

Figure 2. Total Dependency Ratios for New Zealand: Unadjusted and Adjusted by Consumption Weights: 1901-2101

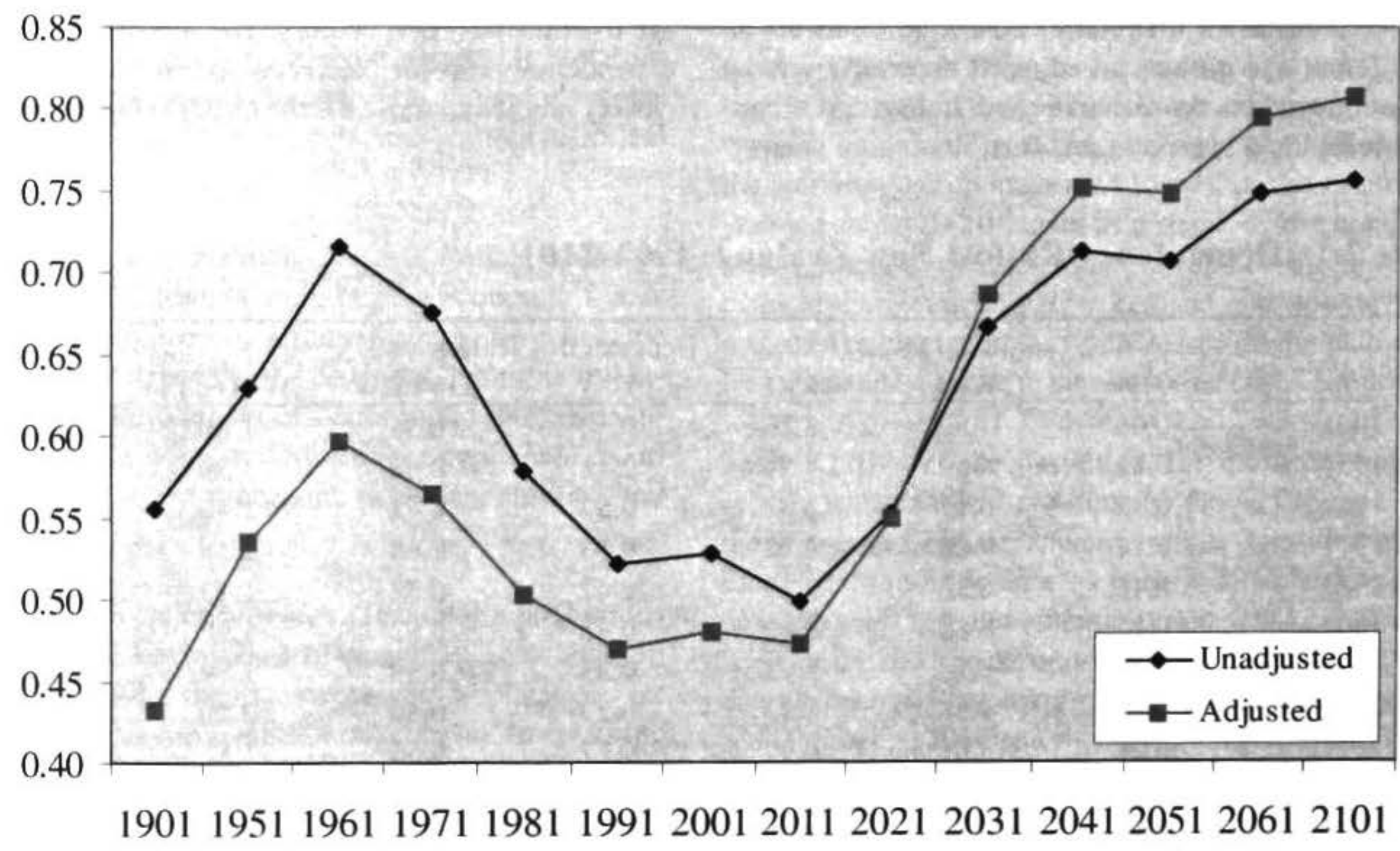




\begin{tabular}{|c|c|c|c|c|c|c|c|}
\hline \multirow[b]{2}{*}{ Year } & \multirow{2}{*}{ Australia } & \multirow{2}{*}{ Canada } & \multirow[b]{2}{*}{ Ireland } & \multirow[b]{2}{*}{ Sweden } & \multirow[b]{2}{*}{ New Zealand } & \multicolumn{2}{|c|}{ OECD Averages } \\
\hline & & & & & & Large & Total \\
\hline 1950 & 12.4 & 12.3 & 17.8 & 15.5 & 14.3 & & \\
\hline 1980 & 14.8 & 14.1 & 18.5 & 25.4 & 15.4 & 19.1 & 18.9 \\
\hline 2000 & 17.5 & 19.0 & 16.9 & 25.1 & 16.3 & 21.9 & 20.8 \\
\hline 2010 & 18.7 & 21.4 & 16.3 & 26.6 & 17.5 & 24.7 & 22.9 \\
\hline 2020 & 23.6 & 28.9 & 18.7 & 33.1 & 23.0 & 29.5 & 27.6 \\
\hline 2030 & 29.0 & 37.3 & 22.7 & 35.4 & 30.7 & 35.2 & 33.3 \\
\hline 2050 & 31.7 & 35.8 & 30.8 & 35.3 & 34.8 & 35.9 & 35.1 \\
\hline \multicolumn{8}{|c|}{ Percentage Changes } \\
\hline $1950-2050$ & 156 & 191 & 73 & 128 & 143 & & \\
\hline $1980-2000$ & 18 & 35 & -9 & -1 & 6 & 15 & 10 \\
\hline $1950-2000$ & 41 & 54 & -5 & 62 & 14 & & \\
\hline $2000-2050$ & 81 & 88 & 82 & 41 & 113 & 64 & 69 \\
\hline
\end{tabular}

Notes:

1.All data from OECD (1988). The large OECD countries are Canada, France, Germany, Italy, Japan, UK and USA 2.The aged dependency ratio is defined as the number of $65+$ as a percentage of the 15-64 age group.

Within the growing elderly population of New Zealand, the share of older persons is projected to rise. The share of the 65-69 year olds will decline, while the share of those over 80 rises markedly (see Table 5 ). This change may well have implications for the total health costs of the elderly.

The question is sometimes raised as to whether the future population structure could be modified by increasing the rate of net immigration. Table 6 shows that even at the highest rates of net immigration reported in the population projections, the effect on the age dependency ratio is modest. In order for New Zealand to maintain its aged dependency ratio in 2021 at the level of 2011 would require a net addition to the working age population of 0.9 million, a 33 percent increase. Even at high historical levels of net migration of 20,000 annually, the total net addition over a decade (assuming all migrants were of work-

Table 4. Total Dependency Ratio: Selected OECD Countries: 1950-2050

\begin{tabular}{|c|c|c|c|c|c|c|c|}
\hline \multirow[b]{2}{*}{ Year } & \multirow[b]{2}{*}{ Australia } & \multirow[b]{2}{*}{ Canada } & \multirow[b]{2}{*}{ Ireland } & \multirow[b]{2}{*}{ Sweden } & \multirow[b]{2}{*}{ New Zealand } & \multicolumn{2}{|c|}{ OECD Averages } \\
\hline & & & & & & Large & Total \\
\hline 1950 & 53.2 & 59.8 & 65.0 & 50.9 & 61.3 & & \\
\hline 1980 & 53.5 & 48.1 & 70.0 & 56.0 & 58.0 & 52.3 & 55.6 \\
\hline 2000 & 49.5 & 47.9. & 52.4 & 51.5 & 47.6 & 49.9 & 50.2 \\
\hline 2010 & 48.2 & 46.6 & 47.3 & 52.5 & 45.7 & 50.7 & 49.5 \\
\hline 2020 & 52.9 & 55.3 & 48.5 & 59.0 & 50.0 & 55.8 & 54.1 \\
\hline 2030 & 59.5 & 66.5 & 54.1 & 63.2 & 58.4 & 63.5 & 61.9 \\
\hline 2050 & 63.0 & 67.7 & 63.2 & 65.0 & 63.4 & 66.0 & 65.7 \\
\hline \multicolumn{8}{|c|}{ Percentage Changes } \\
\hline $1950-2050$ & 18 & 13 & -3 & 28 & 3 & & \\
\hline $1980-2000$ & -7 & 0 & -25 & -8 & -18 & -5 & -10 \\
\hline $1950-2000$ & -7 & -20 & -19 & 1 & -22 & & \\
\hline $2000-2050$ & 27 & 41 & 21 & 26 & 33 & 32 & 31 \\
\hline
\end{tabular}

Notes:

1.All data from OECD (1988). The large OECD countries are Canada, France, Germany, Italy,

Japan, UK and USA.

2.The total dependency ratio is defined as the number of 0-14 plus $65+$ as a $\%$ of $15-64$ age group. 
Figure 3. Aged Dependency Ratio: New Zealand, Australia and OECD Average: 1950-2050

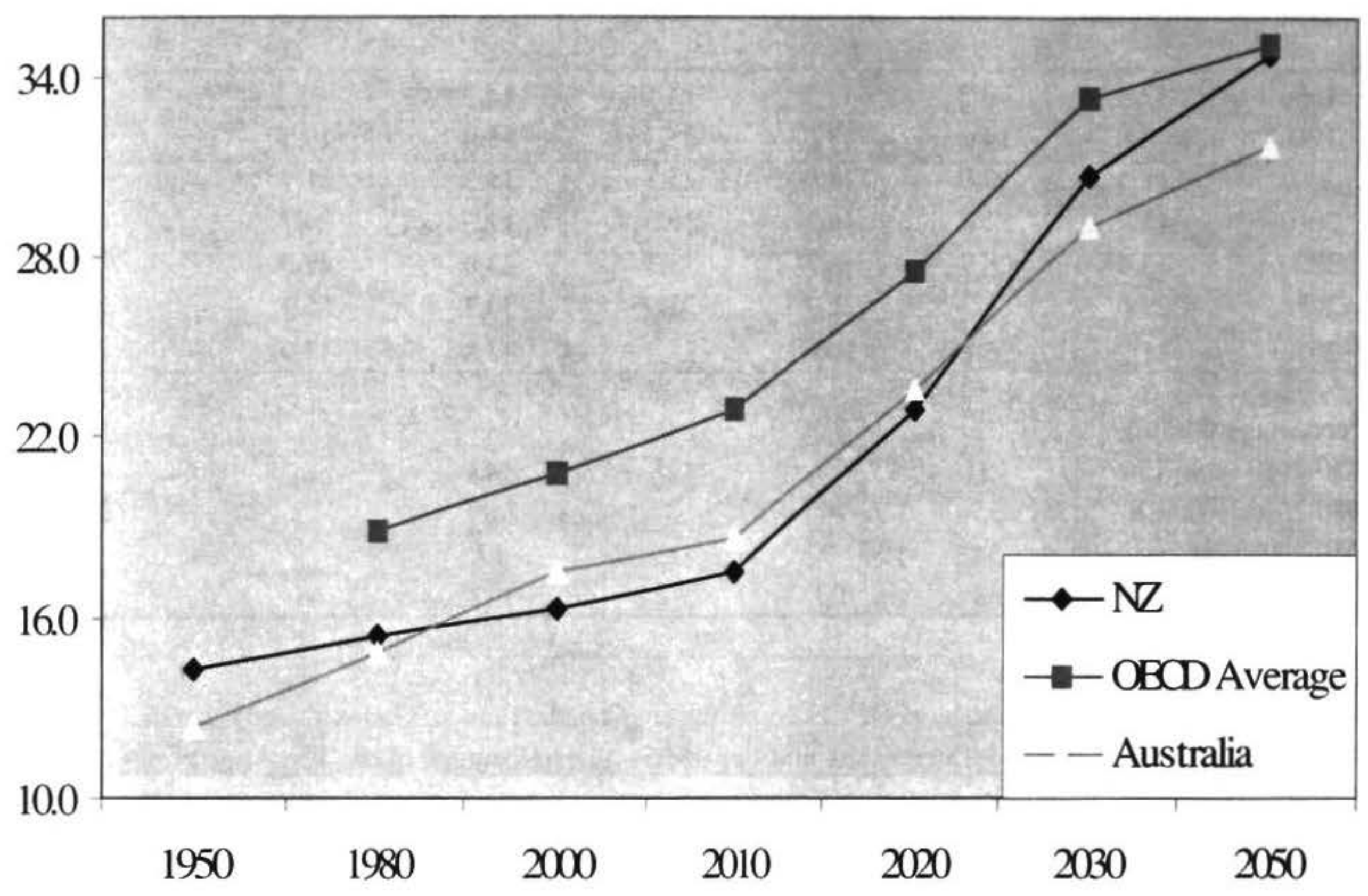

Figure 4. Total Dependency Ratio: New Zealand, Australia and OECD Average

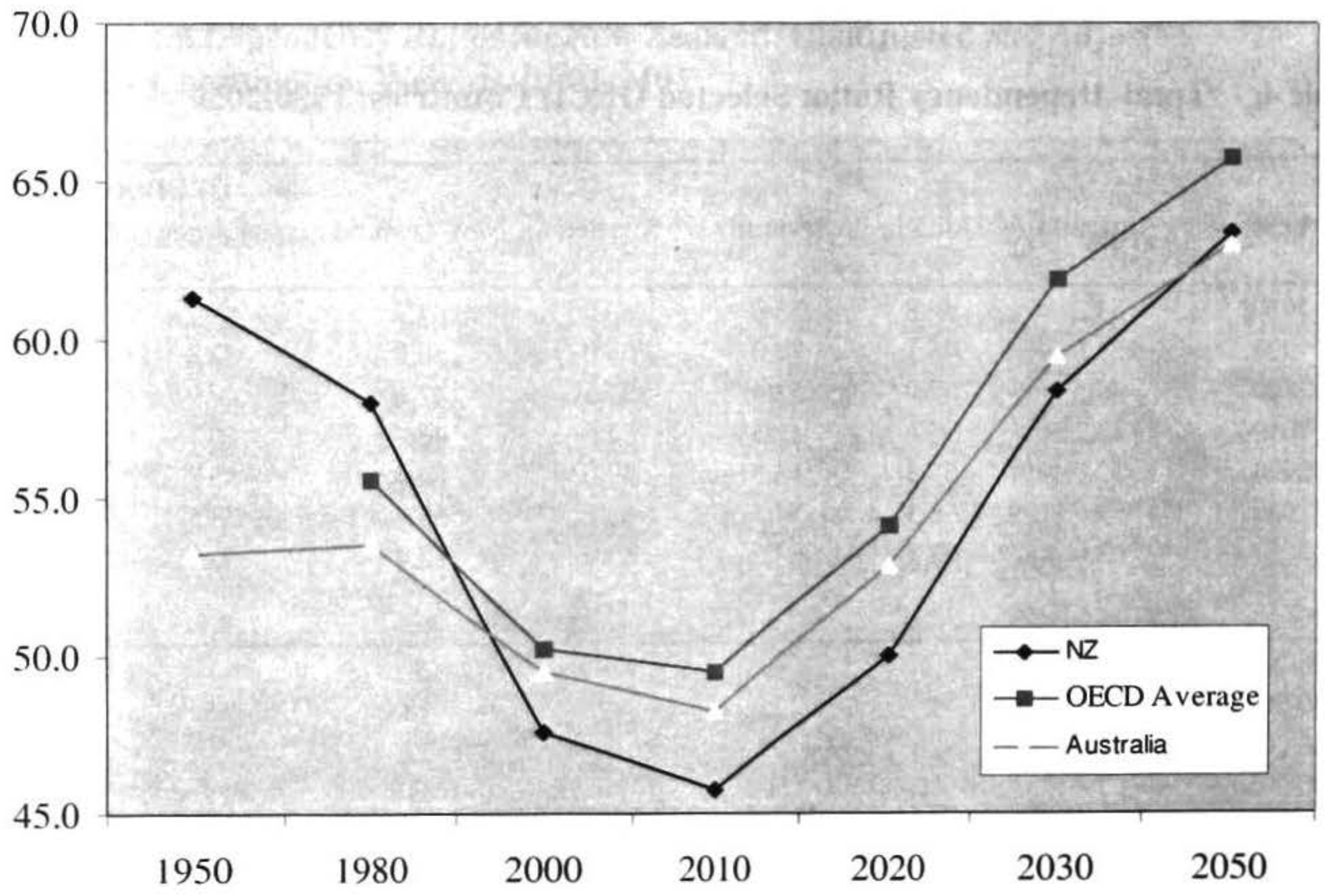




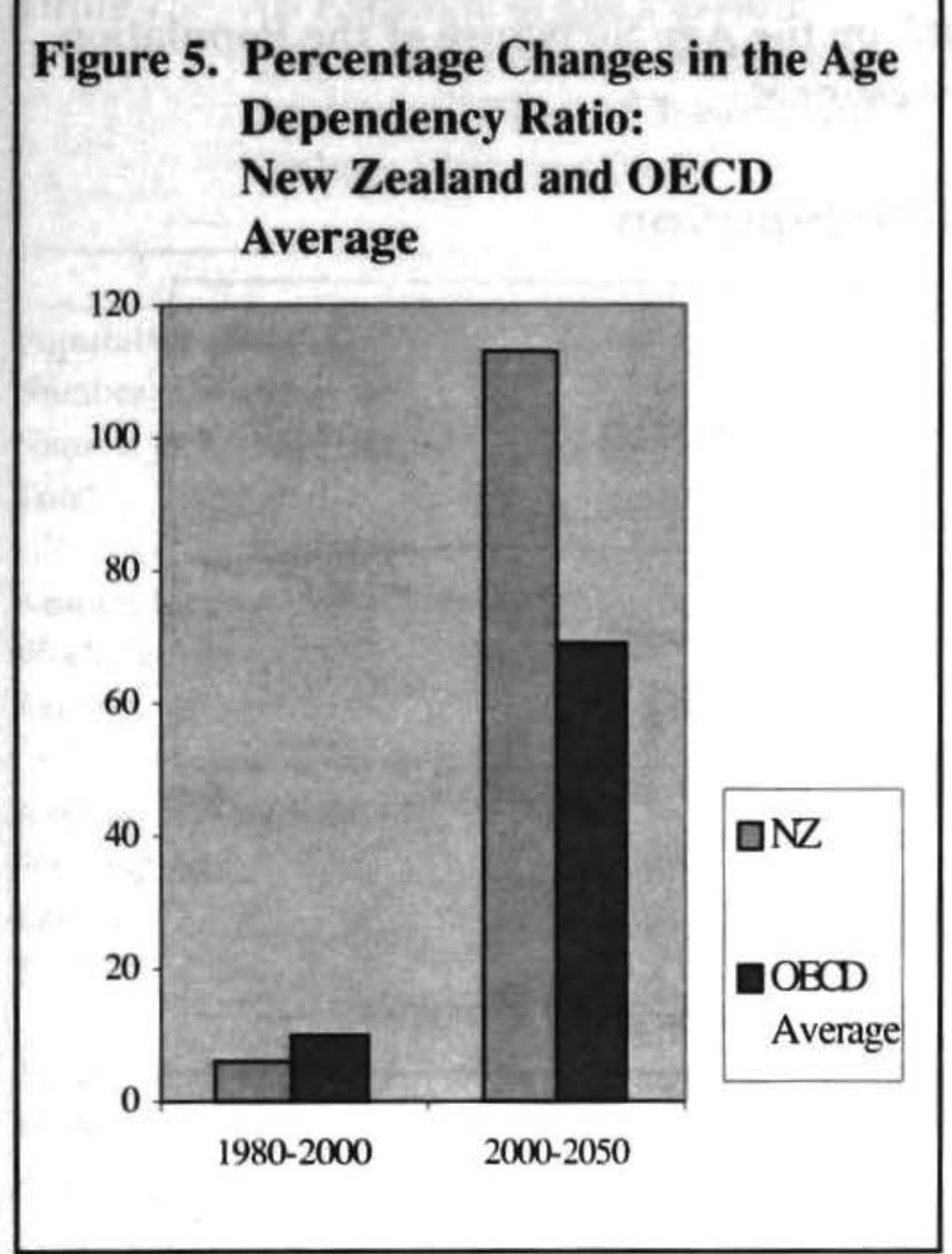

ing age), would amount to only $0.2 \mathrm{~m}$. In sum, it seems improbable that the projected rise in the age dependency ratio could be offset in any significant way through immigration.

Guest and McDonald (2000) present projections of the government expenditure for social outlays under three

\section{Figure 6. Percentage Changes in the Total Dependency Ratio: New Zealand and OECD}

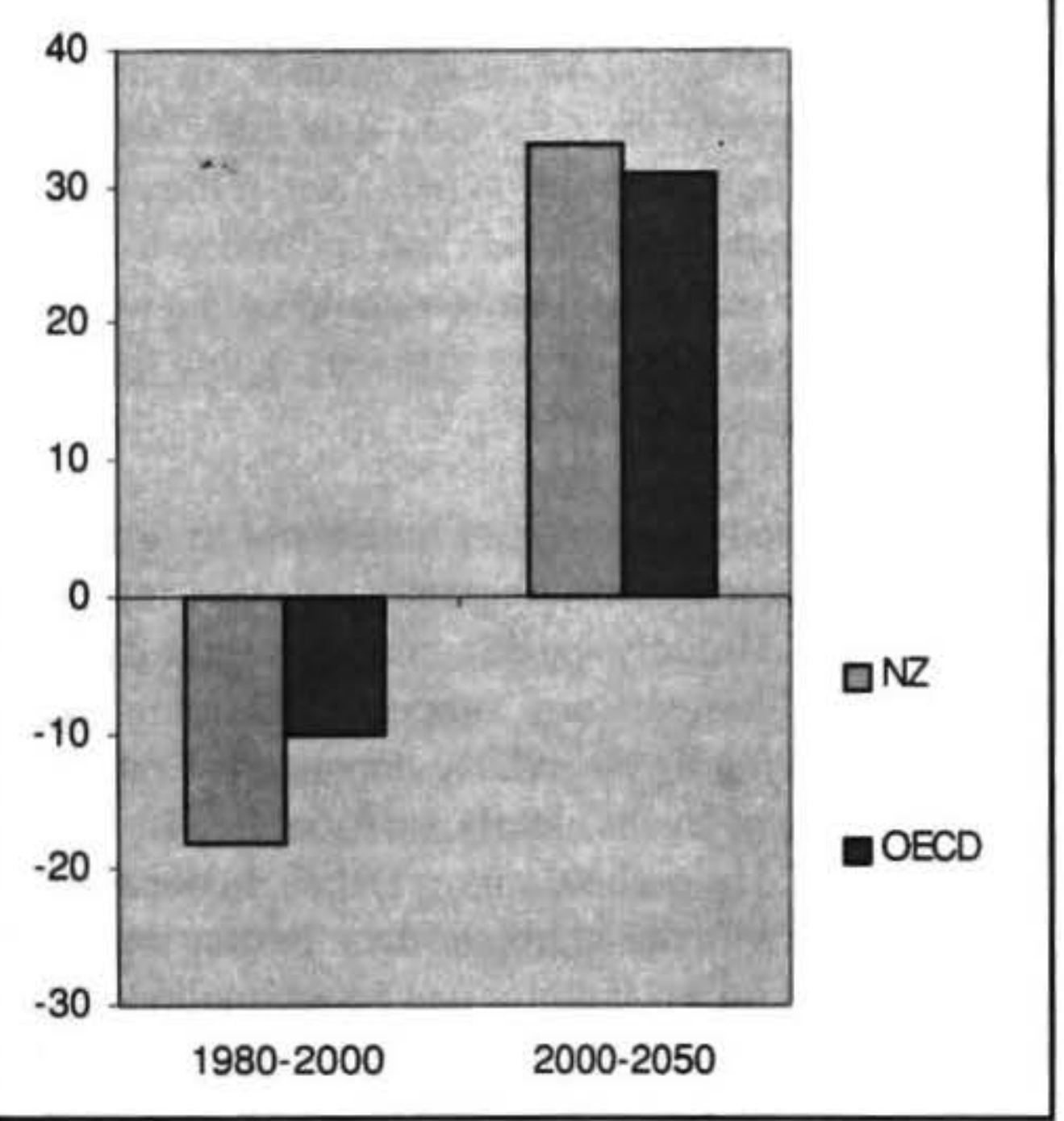

Table 5. Trends in the Age Structure of the Elderly Population: New Zealand: 1980-2050

\begin{tabular}{ccccc}
\hline $\begin{array}{c}\text { Percentage } \\
\text { of } \\
\begin{array}{c}\text { Population } \\
\text { Aged 65+ }\end{array}\end{array}$ & $\mathbf{1 9 8 0}$ & $\mathbf{2 0 0 0}$ & $\mathbf{2 0 3 0}$ & $\mathbf{2 0 5 0}$ \\
\hline $65-69$ & 37 & 30 & 33 & 26 \\
$70-79$ & 47 & 48 & 47 & 45 \\
$80+$ & 17 & 21 & 20 & 29 \\
\hline Total & $\mathbf{1 0 0}$ & $\mathbf{1 0 0}$ & $\mathbf{1 0 0}$ & $\mathbf{1 0 0}$ \\
\hline
\end{tabular}

Source: OECD (1988), Table A.3.

different levels of net immigration. By 2031, social expenditure as a share of GDP is projected to rise to 26.8 percent with a high level of immigration (70,000 annually) and 28.6 percent if there were zero net immigration. This relatively small difference must surely fall within the bounds of forecasting error, and adds further weight to the argument that the burden of aging is little changed by even marked differences in net immigration rates.

In this section we have concentrated on changes in dependency ratios. It should be emphasised however that they are only one, somewhat crude indicator, albeit simple to calculate and interpret. They tell us nothing about the willingness of the working age population to meet the implied transfers, about changes in institutions or social patterns that might emerge as a response to an aging population, how well prepared people are for retirement or the contribution the retired make both within the family and more broadly (Grimmond, 2000). This serves to underscore that the implications of an aging population extend far beyond simple demographic indices to touch economic, social and institutional aspects of society.

\section{Macroeconomic Changes}

What do these demographic changes mean for saving and investment? Will the growth of output be affected? This section considers these questions.

A useful starting point is the results of a simulation presented by Matthews and Higgins (Higgins and Williamson,

Table 6. Estimated Age Dependency Ratios for Three Levels of Net Migration: New Zealand: 2001-2051

\begin{tabular}{cccc}
\hline Year & Zero & Low & High \\
& 0 & 5,000 & 20,000 \\
\hline 2001 & 0.18 & 0.18 & 0.18 \\
2021 & 0.28 & 0.28 & 0.26 \\
2051 & 0.46 & 0.44 & 0.39 \\
\hline
\end{tabular}


Figure 7. Simulated Effect of a "Baby Boom" on the Age Structure of the Population and on the Flow of Saving and Investment

Population Age Distribution

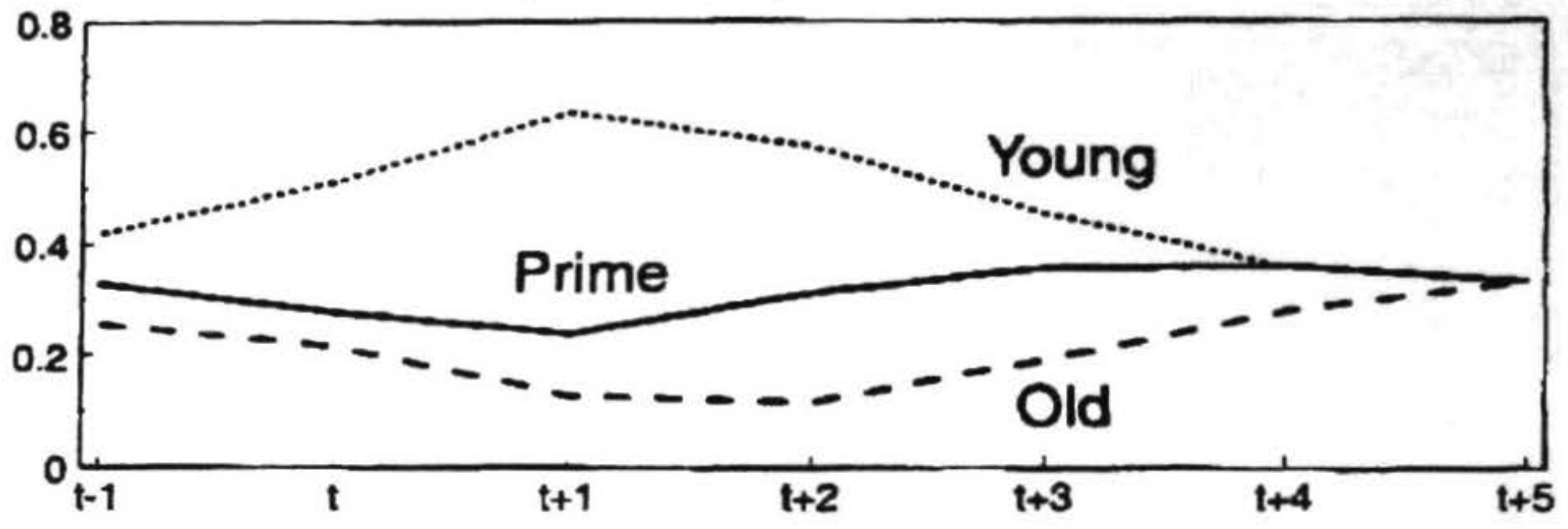

Savings and Investment Rates: The Open Economy

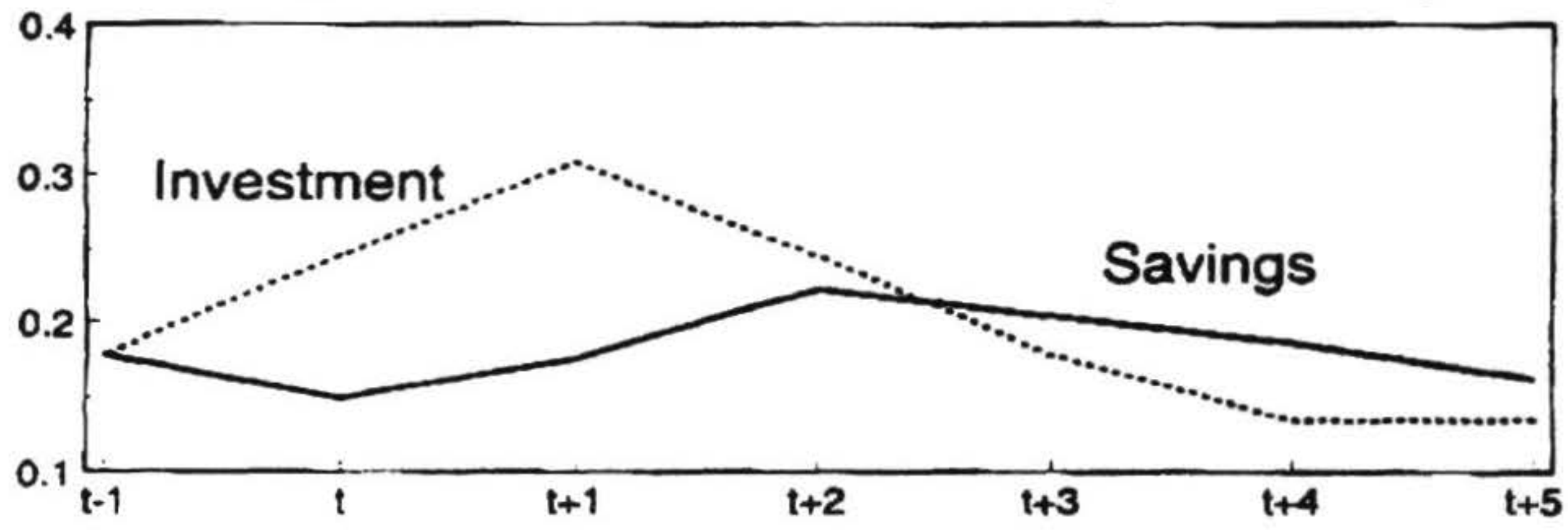

Source: Matthew and Higgins (1996).

1966). For a stylised economy they start from a steady state and then allow the fertility rate to rise, after which it gradually declines to a new lower steady state level. In other words their model simulates the baby-boom phenomenon. The age distribution of the population now evolves with the share of the young rising sharply to start with, and then declining. Mean while the share of the prime age and the old initially fall. But then there is a marked increase in the share of the old as the baby boomers pass through their life cycle.

These trends and their implications for saving and investment are plotted in Figure 7. As a result of the higher dependency burden at the start, savings fall, but increase in line with the prime age population as the baby boomers moves into their higher saving periods of the life cycle. With the increase in new entrants to the labour force, investment increases in order for the capital labour ratio to remain constant. As fertility declines, the investment rates subsequently declines to a new steady state level. In an open economy, the current account balance follows the evolution of saving and investment. The initial fall in saving and the increased investment needs imply a current account deficit for the younger growing economy as it imports capital. As the population matures, so the current account balance improves.

These results mirror the life cycle hypothesis in which the prime age population (especially at the upper end of this range) account for much of the total private saving as they prepare for retirement. As a consequence, an increase in the elderly dependency ratio should be associated with a sharp decline in household saving. Even if the elderly do not actually decumulate assets and continued to save (as some evidence suggests) then household saving would still decline provided their saving rate was below that of the working-age population.

Given the already low level of household saving, a prediction of further falls as the population ages might well be of concern. Broadly speaking the aggregate data from cross-country comparisons, support a declining level of household saving as the elderly dependency ratio rises. Yet when savings by the elderly are estimated from micro data (individual household surveys) they do not appear to fall consistent with the aggregate data. Disney argues that the macro and micro findings can be reconciled through the role played by bequests (Disney, 1996). 
Table 7. An Estimate of the Possible Effect of Population Aging on the Annual Flow of Household Saving: 2001 and 2051

\begin{tabular}{|c|c|c|}
\hline & 2001 & 2051 \\
\hline \multicolumn{3}{|l|}{ Population ('000) } \\
\hline Number of Working Age & 2,526 & 2,712 \\
\hline Number of Retirees & 457 & 1,181 \\
\hline Total & 3,861 & 4,630 \\
\hline \multicolumn{3}{|l|}{ Annual Income ('000) } \\
\hline Working Age & 40 & 84 \\
\hline Retirees & 20 & 42 \\
\hline \multicolumn{3}{|l|}{ Average Saving Rate (\%) } \\
\hline Working Age & 15 & 15 \\
\hline Retirees & 10 & 10 \\
\hline Total & 14.2 & 13.5 \\
\hline \multicolumn{3}{|l|}{ Saving (\$million) } \\
\hline Working Age & 15,156 & 34,257 \\
\hline Retirees & 914 & 4,973 \\
\hline Total Household Saving & 16,070 & 39,229 \\
\hline \multicolumn{3}{|l|}{ Total Supply of Funds } \\
\hline As share of GDP & 0.15 & 0.17 \\
\hline
\end{tabular}

However, the observed lack of decline in saving rates by the elderly may be due to mis-measuremnt. If, as Miles argues, the payments to the elderly from private pensions are counted as income with no allowance made for the depletion of capital as the fund is drawn down, then saving rates among the elderly may be systematically overstated by this mis-measurement (Miles, 1999). Bosworth et al calculated US saving rates with and without the adjustment for pension wealth, finding that for households over 64 years of age the adjustment reduced the meas- ured saving rate from $14.9 \%$ to $1.8 \%$ in $1972-73$, from $11.5 \%$ to $-3.9 \%$ in $1982-85$ (Bosworth, Burtless and Sabelhaus, 1991). Clearly this effect will be greater where private and occupational pensions form a greater share retirement income than in New Zealand, where the majority of total income is from the PAYG system of tax and transfer.

Table 7 summarises an attempt to assess the effects on household saving arising from changes in the demographic structure. I have assumed that income grows at 1.5 percent per annum and that the average saving rates do not change between 2001 and 2051. Some what surprisingly, despite the effect of population aging, total savings would still rise roughly in line with income. In fact as shown in the last line of the table, the overall supply of household saving as a share of GDP remains constant. Assuming that investment needs rise in line with GDP growth (ie. assuming a constant capital:output ratio) and that there is no significant change in public saving, then the balance between domestic saving and investment requirements would not be expected to alter dramatically.

The sheer increase in the numbers of the elderly, even if their saving rate was only modestly lower than the working-age population, would seem to support the case for predicting a fall in private saving. To examine this in more detail, age-specific saving rates are required. Data for forming such estimates are scarce. One possible source is the Household Economic Survey. A preliminary estimate of the median saving rate was made. Only households where the age of the head was between 20 and 70 were included, and households reporting negative disposable incomes were excluded. The value for the group of 70 and older was assumed to be half that of the 60-69 age group.

The results are shown in Table 8. When these are weighted by the projected population in each age category, there is little change in the overall median household saving rate

Table 8. Impact of Changes in the Population Age Structure on the Median Household Saving Rate in New Zealand : 2001-2041

Population ('000)

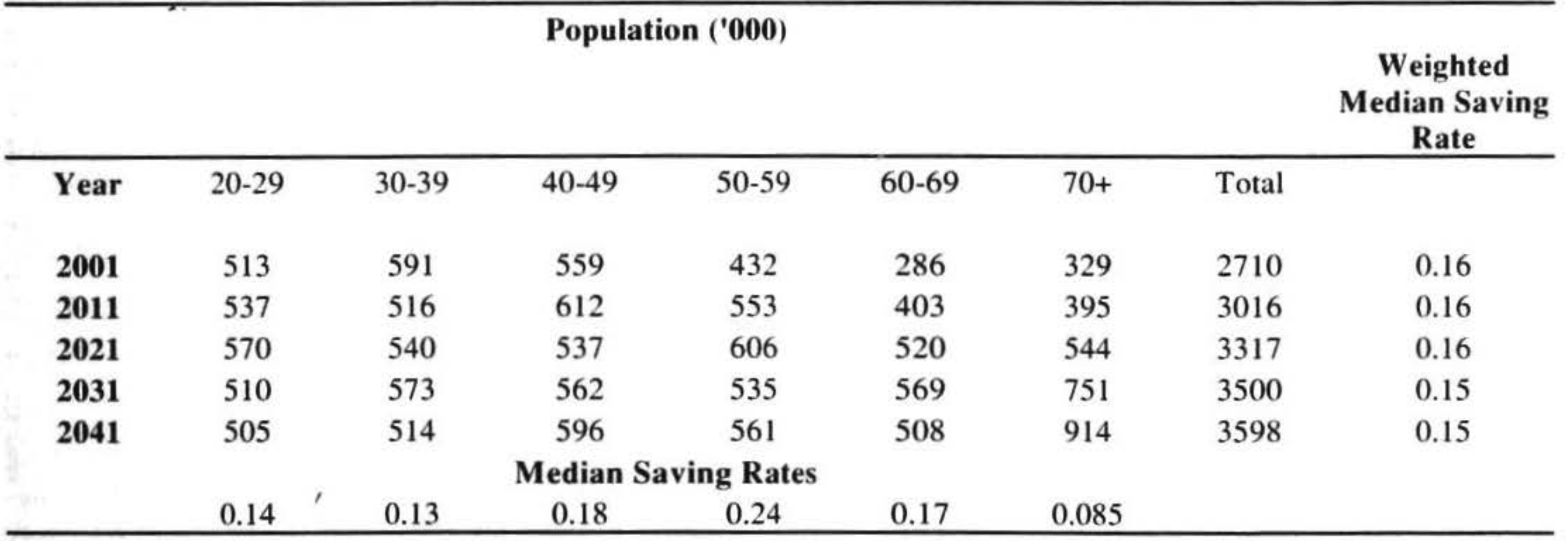

Notes: 1. The last row are the median saving rates from the HES

2. The value $70+$ group is taken as half the $60-69$ group. 
from 2001 to 2041 . This is consistent with the result that the total supply of household saving would not decline significantly despite the increase in the share of the elderly.

What evidence do we have from other countries? Studies by Weil (Weil, 1994) and Disney (Disney, 1996)based on 9 and 19 OECD countries respectively shed some further light on the relation between the age structure and the level of household savings. Based on these results, moving one percent of the total population from the working age to the retired aged group would be associated with a fall in savings of between 1 and 2 percent. Between 2021 and 2031 approximately 5 percent of the New Zealand population will move from the working to the retired age group. Were New Zealand saving behaviour to mirror the long run patterns of other OECD countries we could expect this to result in a fall in savings of between 5 and 10 percent. Of course if household saving continues to represent a relatively small share of national saving (say less than 20 percent), then the impact on aggregate saving would likely be modest.

Disney (1996) also presents results for investment and growth rates based on 19 OECD countries for 1977-1992. The rate of investment is found to be negatively related to the aged dependency ratio. If we again apply this finding to New Zealand, then between 2021 and 2031 we would predict a fall in the growth rate of gross fixed capital formation by 0.7 percent pa. From the same study we can extrapolate the overall OECD effect of aging on GDP growth rates to New Zealand. Our aged dependency ratio is projected to rise from 0.21 in 2021 to 0.38 in 2031 . This factor alone would be expected to reduce real economic growth rates by 0.5 percent annually.

For New Zealand, a recent preliminary study by Choy finds weak evidence for a negative effect on saving from the rise in age dependency based on data from 1978 to 1999. Extrapolating from this estimate, suggests that the projected rise in age dependency could be expected to reduce the household saving rate very substantially (Choy, 2000). The difficulty with using this and other retrospectives studies as a source of behavioural response parameters for forecasting is that future changes in the age dependency fall well outside historical experience. It is unlikely that the same parameter values would apply to such changed circumstances, meaning that history can be only a limited guide. Furthermore, these forecasts depend on the particular policy settings adopted by New Zealand as well as any changes in the behavioural response parameters themselves.

\section{The Global Economy}

Changes in national levels of saving and investment as a consequence of demographic changes have implications beyond national borders in a world where countries are linked through goods, labour and capital markets. Imagine a simple world of only two countries. In country A there is a high youth dependency ratio associated with a growing population. The demand for capital is high and Country $\mathrm{A}$ has a current account deficit. In contrast the population of country B is aging, and tending to become a capital exporter on the assumption that the demand for investment falls faster than saving. Capital flows from the surplus to the deficit country.

If growing economies in the developing world are able to finance more of their own investment needs from domestic saving, Higgins argues this would reinforce "the trend toward global capital abundance". (Higgins, 1998). He concludes his study with the prediction that in OECD countries the saving rate will fall, and current account surpluses increase over the next two decades. This finding is supported by an OECD study.(OECD, 1988) Faster growing developing countries, will remain capital importers in the medium term. However in the longer term they are expected to become net capital exporters

The emergence of current account surpluses in the OECD over the next two decades arises from changes in the desired saving and investment balances. With a relatively smaller labour force, capital requirements would grow less rapidly than in the past, assuming a constant capital:labour ratio. This would dampen domestic investment requirements. At the same time there could be a rise in saving as those who will retire around 2020 move through the life stages where saving is typically higher. In addition there may well be some increment to national savings from the prefunding of public pension schemes.

The result of these trends in desired saving and investment levels would be for the stock of net foreign assets of the OECD to build up in the non-OECD regions. However, as the numbers retiring increase significantly from 2020 on, then this stock of assets would be drawn down. This would be accompanied by current account deficits. However it is through intertemporal transfer of assets that the negative impact on living standards can be partially ameliorated. In the absence of such a global mechanism, higher taxes on the working age population and/or reduced levels of real consumption by the retired would be more likely in an aging population. This serves to underscore the importance of global capital markets.

The standard argument is that these markets contribute to increasing the overall return to scarce global capital, by signally its allocation to those regions where the returns are highest. In the context of changes in the age structure of whole populations, global capital markets assume an additional role by allowing capital to move across borders in a manner equivalent to an intergenerational transfer.

Critical to any long-term projections, is what might happen to interest rates and asset prices. The trends in saving and investment suggested by the aging population suggest that initially one might expect a period of relatively stable or lower interest rates and increasing prices for real and financial assets as the demand for them rises as the higher saving cohorts move through their peak saving 
Figure 8. Growth Rate of the New Zealand Labour Force: 1998-99 to 2050-2051

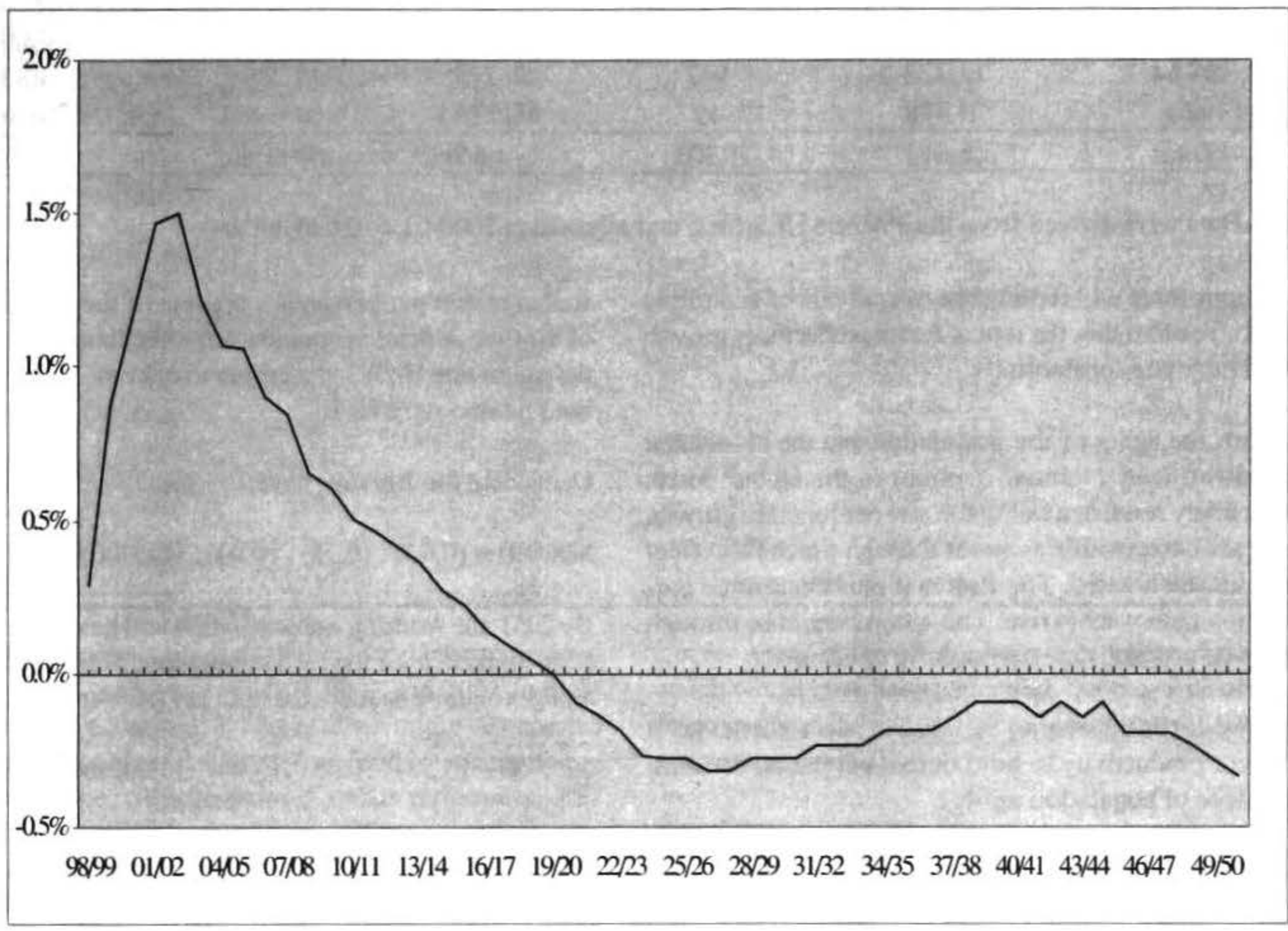

Source: The Treasury: Long-term Fiscal Model.

years. The rise in equity prices generally in the 1990's may well be related in part to the large increase in volumes of private savings directed into mutual funds.

As those cohorts them move through the retirement phase of their life cycle and start to sell off assets (either through privately held pension schemes or through prefunded public schemes) then it is to be expected that there would be downward pressure on asset prices. This would be accentuated by the fact that most OECD countries will be experiencing a similar pattern of contemporaneous changes in the demographic age structures.

\section{Labour Market and Growth}

Commensurate with the aging population, it is expected that the growth in the labour force will decline and eventually become negative (Figure 8 ). There are two potentially important consequences. The first concerns the impact of an aging labour force. If it is the case that labour productivity increases through the working life, then at least up to some point, the overall effect on productivity in the short run may well be favourable as the working age population ages.

The second impact stems from the slower growth of the labour force. Total economic growth can be decomposed into three key components: the growth rate of the labour force (weighted by the share of labour); the growth rate of the capital stock (weighted by the share of capital): and the growth rate of total factor productivity.

If the capital:output ratio is assumed to remain constant, then the overall rate of economic growth depends only on the growth of the labour force (along with labour's share), together with the overall growth in productivity. When the labour force is growing at 1 percent and overall productivity at say a long run average of also 1 percent, then the economic growth rate would be 2.7 percent annually (based on a labour share of 0.6). However in the period 2025-2030 the labour force is expected to be declining by -0.3 percent annually. Even if the productivity growth remained unchanged, the overall rate of economic growth would slow to around 1.4 percent. In other words the fall in the growth of the labour force could potentially cut the overall economic growth rate by almost one half.

Of course this slowdown could be offset were the rate of total factor productivity growth to rise. To maintain the initial rate of growth of 2.7 percent however, productivity growth would need to rise from the starting level of 1 percent annually to 1.8 percent, a significant rise indeed. In summary, projected declines in the rate of growth of 
Table 9. Unit Costs per Capita for Public Expenditure by Age Groups

\begin{tabular}{cccccc}
\hline Age Group & Health & Education & NZ Super & Other Welfare & Total \\
\hline $\mathbf{0 - 1 4}$ & & & & & \\
$\mathbf{1 5 - 6 4}$ & 1,675 & 2,928 & 0 & 0 & 4,603 \\
$\mathbf{6 5 +}$ & 1,122 & 947 & 273 & 2,492 & 4,834 \\
\hline Total & 4,478 & 12 & 11,912 & 464 & 16,866 \\
\hline
\end{tabular}

Note: Data were derived from the 1997-98 HES files, and adjusted to 2000-01 constant dollars

the labour force will reduce the overall rate of economic growth. To offset this, the rate of factor productivity growth would have rise substantially.

In short, the aging of the population and the associated slow down (and eventual decline) in the labour force, would likely result in a fall in the rate of economic growth. There are two possible avenues through which this effect could be ameliorated. The first is if the labour force participation rates were to rise. The second would be through improved productivity, particularly of labour.

What would be the overall increase in needed in the level of labour productivity to hold output per person constant in the face of population aging?

To address, consider the following relationship:

$(\mathrm{O} / \mathrm{P})=(\mathrm{W} / \mathrm{P}) \cdot(\mathrm{L} / \mathrm{W}) \cdot(\mathrm{E} / \mathrm{L}) \cdot(\mathrm{O} / \mathrm{E})$

where:

$\mathrm{O}=$ total output

$\mathrm{P}=$ total population

$\mathrm{W}=$ working age population

$\mathrm{L}=$ labour force

$\mathrm{E}=$ employment so that output per person is a product of the complement of the total dependency ratio (W/P), the labour force participation rate $(\mathrm{L} / \mathrm{W})$, the employment rate $(\mathrm{E} / \mathrm{L})$ and labour productivity (O/E).

Using data for 2001 we have:

$\$ 28,000=(0.65) \cdot(0.75) \cdot(0.94) \cdot(61,000)$

By 2051, the working age population will have fallen from 65 to 58 percent of the total population. The effect of this aging would be to reduce output per person to:

$\$ 24,900=(0.58) \cdot(0.75) \cdot(0.94) \cdot(61,000)$

or by 11 percent. In order to hold real output per person constant, labour productivity would have to rise by 12 percent to $\$ 68,000$.

$\$ 28,000=(0.58) \cdot(0.75) \cdot(0.94) \cdot(68,000)$.

That is, simply to retain the current level of command over real goods and services per capita, the level of labour productivity would have to rise by 12 percent to offset the effect of aging, before any increments to real output growth were achieved.

Table 10. Impact of Projected Demographic Change on Total Social Expenditure $(2000-2001=100)$

\begin{tabular}{cccccc}
\hline Year & Health & Education & \multicolumn{2}{c}{ Social Welfare } & Total HEW \\
\cline { 3 - 5 } & & & Super & All Other & \\
\hline 1901 & 18 & 25 & 8 & 20 & 18 \\
1951 & 49 & 56 & 40 & 47 & 48 \\
1961 & 61 & 74 & 47 & 55 & 58 \\
1971 & 71 & 86 & 55 & 67 & 69 \\
1981 & 80 & 88 & 70 & 79 & 79 \\
1991 & 88 & 90 & 86 & 89 & 88 \\
2001 & 100 & 100 & 100 & 100 & 100 \\
2011 & 110 & 101 & 122 & 110 & 111 \\
2021 & 125 & 100 & 164 & 114 & 127 \\
2031 & 142 & 99 & 212 & 112 & 143 \\
2041 & 150 & 97 & 239 & 112 & 152 \\
2051 & 151 & 95 & 241 & 112 & 152 \\
2061 & 152 & 94 & 249 & 109 & 153 \\
2101 & 142 & 86 & 234 & 101 & 143 \\
\hline
\end{tabular}


Table 11. Total Social Welfare Costs in $2001 \$$ with Health and Super Growing at $1.5 \%$ pa (2000- 2001=100)

\begin{tabular}{cccccc}
\hline Year & Health & Education & \multicolumn{2}{c}{ Social Welfare } & Total HEW \\
\cline { 3 - 5 } & & & Super & All Other & \\
\hline 1901 & 18 & 25 & 8 & 20 & 17 \\
1951 & 48 & 56 & 40 & 47 & 47 \\
1961 & 60 & 74 & 47 & 55 & 58 \\
1971 & 71 & 86 & 55 & 67 & 69 \\
1981 & 80 & 88 & 70 & 79 & 79 \\
1991 & 88 & 89 & 85 & 89 & 88 \\
2001 & 100 & 100 & 100 & 100 & 100 \\
2011 & 128 & 101 & 142 & 110 & 121 \\
2021 & 169 & 100 & 221 & 114 & 153 \\
2031 & 222 & 99 & 332 & 112 & 195 \\
2041 & 273 & 97 & 434 & 112 & 234 \\
2051 & 317 & 95 & 508 & 112 & 264 \\
2061 & 371 & 94 & 608 & 109 & 303 \\
2101 & 628 & 86 & 1039 & 101 & 478 \\
\hline
\end{tabular}

Note that the same rates of labour force participation and employment were used for both 2001 and 2051 in making the above estimates. Rising incomes might be expected to increase the demand for leisure and lower participation rates especially in form of earlier retirement. This trend has been evident in the past. Lower participation rates may also emerge in future if the demand for highly skilled workers leads to longer periods of tertiary education and training. In contrast, increased life expectancies may tend to offset the tendency to earlier retirement. These issues warrant further research.

If tax increases are needed to meet higher social costs associated with aging, then a disincentive effect on labour supply could arise. Guest and McDonald (2000) show that for Australia the effect is to reduce income below that which would have been generated, but the costs of social programmes as a share of GDP only increases by 0.6 to 1.2 percentage points.

\section{Fiscal Costs}

What might an aging population mean for public sector expenditures? This question is important for a number of reasons. If the costs are expected to rise, will taxation revenues grow commensurately? Would it imply that the existing level of social benefits provided by the state might not be maintained? And what would it mean for public saving levels? As we have seen in recent years, public saving has been a major element of aggregate national

Table 12. Total Social Expenditure Costs per Capita of Working age Population: $(\mathbf{2 0 0 0}-2001=100)$

\begin{tabular}{cccccc}
\hline \multicolumn{5}{c}{$\begin{array}{l}\text { Total Social Welfare Costs in 2001\$ per capita 15-64 } \\
\text { Health \&Super Growing at 1.5\% pa }\end{array}$} \\
\cline { 1 - 4 } Year & Health & Education & \multicolumn{2}{c}{ Social Welfare } & Total HEW \\
\cline { 3 - 5 } 1901 & & & Super & All Other & 85 \\
1951 & 103 & 121 & 40 & 97 & 100 \\
1961 & 108 & 119 & 84 & 99 & 104 \\
1971 & 105 & 132 & 84 & 99 & 102 \\
1981 & 100 & 127 & 81 & 99 & 99 \\
1991 & 98 & 111 & 88 & 99 & 98 \\
2001 & 100 & 95 & 99 & 100 \\
2011 & 117 & 100 & 100 & 100 & 111 \\
2021 & 151 & 92 & 130 & 102 & 137 \\
2031 & 205 & 89 & 198 & 104 & 180 \\
2041 & 255 & 92 & 306 & 105 & 218 \\
2051 & 295 & 90 & 405 & 105 & 246 \\
2061 & 358 & 89 & 473 & 105 & 292 \\
2101 & 657 & 90 & 586 & 105 & 500 \\
\hline
\end{tabular}


Table 13. Per Capita Social Expenditures by Age Group, and Projected Changes in the Level and Burden of Total Social Expenditures: Selected OECD Countries and Comparison with New Zealand

\begin{tabular}{cccccccc}
\hline & $\begin{array}{c}\text { Per Capita Social Expenditures } \\
\text { relative to }\end{array}$ & \multicolumn{3}{c}{$\begin{array}{c}\text { Impact of Projected Demographic Change } \\
(\mathbf{1 9 8 0}=\mathbf{1 0 0})\end{array}$} \\
Country & \multicolumn{2}{c}{ 15-64 age group } & & Social Expenditure & $\begin{array}{c}\text { Financing Burden per } \\
\text { head of 15-64 age group }\end{array}$ \\
& & & & & & & \\
& $\mathbf{0 - 1 4}$ & $\mathbf{1 5 - 6 4}$ & $\mathbf{6 5 +}$ & $\mathbf{2 0 1 0}$ & $\mathbf{2 0 4 0}$ & $\mathbf{2 0 1 0}$ & $\mathbf{2 0 4 0}$ \\
\hline Canada & 1.4 & 1.0 & 3.7 & 141 & 187 & 109 & 145 \\
France & 1.9 & 1.0 & 5.1 & 116 & 128 & 104 & 132 \\
W.Germany & 1.7 & 1.0 & 5.3 & 104 & 97 & 113 & 154 \\
Italy & 0.9 & 1.0 & 3.5 & 108 & 107 & 106 & 139 \\
Japan & 2.3 & 1.0 & 5.3 & 141 & 140 & 137 & 154 \\
UK & 1.9 & 1.0 & 4.0 & 101 & 110 & 96 & 111 \\
USA & 1.5 & 1.0 & 5.7 & 125 & 165 & 99 & 131 \\
New Zealand & $\mathbf{0 . 9}$ & $\mathbf{1 . 0}$ & $\mathbf{3 . 5}$ & $\mathbf{1 4 0}$ & $\mathbf{1 9 2}$ & $\mathbf{1 0 2}$ & $\mathbf{1 4 2}$ \\
\hline
\end{tabular}

Source: OECD data from OECD (1988).

saving. Furthermore, expectations of changes in public spending can induce changes in the level of private saving.

In this section we adopt a simple approach to estimating the effect of an aging population on public expenditure. We restrict the focus to expenditure on health, education and welfare (the latter split into superannuation and all other benefits). The aim is to look solely at the influence of a changing age structure of the total costs of these services, and to relate that costs to some measures of the economy's capacity to bear them. In other words we wish to isolate the demographic changes from all other effects. To do this we apply standard per capita unit costs for the period from 1901 to 2101 . Clearly there have been significant changes in the policies governing these expenditures in the past, and one can confidently predict further changes in future. However the purpose here is to abstract from the policy changes and capture the "pure" demographic shifts.

The standard costs were estimated on a per capita basis from the 1997-87 Household Economic Survey and then adjusted for inflation to 200-01 (see Table 9). These are then applied to the population in each of the three key age groups $(0-14,15-64,65$ and over $)$ in order to estimate the total costs in each of the selected years. The results are shown in Table 10.

The first point to note is that the total costs while continuing to rise, do so more slowly than in the past. Since 1950 total costs half doubled, driven by increases in the total population. However, despite the aging of the population, total costs are projected to rise by only about one half in the next 50 years. There are predictably, large differences in the components of expenditure. Slow growth in the population means lower relative numbers of young peo-

ple so education costs fall (note that for simplification all the public education costs are assigned to the 0-14 year old group). The marked change is in the costs of superannuation. Driven by an aging population these would more than double between now and 2030. They would eventually rise to over 40 percent of the health, education and welfare budget from around 20 percent in 1980.

We repeat the calculations and allow unit health and superannuation costs to grow at 1.5 percent annually in line with the assumed overall rate of growth of real GDP. The results in Table 11 serve to underscore the importance of superannuation costs as the population ages.

Table 14. Projected Public Expenditure on Pensions and Health : Selected OECD Countries and Comparison with New Zealand: 2030

\begin{tabular}{lccc}
\hline & $(\%$ GDP $)$ & & \\
\hline \multicolumn{1}{c}{ Country } & Pensions & Health & Total \\
& & & \\
\hline Australia & 3.8 & 7.6 & 11.6 \\
UK & 5.5 & 7.0 & 12.0 \\
USA & 6.6 & 8.2 & 15.2 \\
New Zealand & $\mathbf{9 . 4}$ & $\mathbf{8 . 9}$ & $\mathbf{1 8 . 3}$ \\
Canada & 9.0 & 10.3 & 19.3 \\
Japan & 13.4 & 6.3 & 19.3 \\
France & 13.5 & 8.9 & 21.9 \\
Germany & 16.5 & 7.8 & 24.8 \\
Italy & 20.3 & 8.1 & 28.1 \\
\hline
\end{tabular}

Sources: OECD (1996) and see Guest and McDonald (2000) NZ data from LTFM 
Table 15. Projected Public Expenditure for Health, Education and Welfare: New Zealand and Australia

\begin{tabular}{c|cccc|cccc}
\hline \multicolumn{8}{c}{ (\% of GDP) } \\
\hline Year & Health & Education & Welfare & Total & Health & $\begin{array}{c}\text { Australia } \\
\text { Education }\end{array}$ & Welfare & Total \\
\hline 2001 & 6.6 & 5.6 & 12.6 & 24.8 & 5.7 & 4.6 & 10.3 & 20.6 \\
2011 & 6.4 & 5.9 & 12.3 & 24.6 & 6.1 & 4.2 & 10.9 & 21.2 \\
2021 & 7.4 & 5.5 & 13.8 & 26.7 & 6.9 & 4.1 & 12.4 & 23.4 \\
2031 & 9.0 & 5.4 & 16.2 & 30.6 & 7.9 & 4.1 & 13.8 & 25.9 \\
2041 & 10.3 & 5.5 & 17.6 & 33.3 & 8.6 & 4.1 & 14.6 & 27.3 \\
2051 & 10.9 & 5.3 & 18.0 & 34.2 & 8.9 & 4.1 & 15.0 & 28.0 \\
\hline
\end{tabular}

Sources: NZ LTFM: Version BPSBUP and for Australia, Guest and McDonald (2000).

It is pertinent to enquire as to the "burden" these costs might represent. There are a number of ways in which this might be assessed. In the first instance the costs per capita on the working age are estimated. The rationale for this is that all the resources consumed in these activities must come from the production of the working age population. These results are summarised in Table 12. Again the superannuation costs stand out.

However, as incomes can be expected to grow, it is not entirely fair to assess the burden in per capita terms (which implicitly assumes constant real incomes). To address this we allow the average income of the 15-64 year old group to grow at 1.5 percent annually until 2101 . We then calculate the share of average income that is represented by the growing total health, education and welfare budget. If these costs are currently 28 percent of the average wage, they would rise to 34 percent by 2041 , a 20 percent increase. The rises until 2021 are modest, with the greatest increase coming in the decade from 2021 to 2031.

Finally, how do these trends in the fiscal costs of social expenditures in New Zealand compare with other countries? Table 13 compares the levels and the "burden" of growing expenditures for selected OECD countries. New Zealand appears to be at the upper end of the distribution but not outside the range of projected costs in other countries.

Another perspective on our relative position can be gained by comparing the projected share of GDP that would be needed to meet rising social expenditures. Table 14 suggests that by 2030 the expenditure on pensions and health as a share of the GDP will fall comfortably within the range expected for major OECD countries. While the composition and timing may differ, the total effect projected for New Zealand should not be seen as abnormal.

A more direct comparison with Australia is made in Table 15 . Over the crucial period from 2001 to 2031 , social expenditures in New Zealand are projected to rise by 5.8 percentage points of GDP. The comparable figure for Australia is $\mathbf{5 . 3}$. In every category while there are minor differences in the level and timing of changes the overall growth in social expenditure is remarkably similar.
One implication of this is the possible increases in taxation necessary to meet these costs. Concern is sometimes raised that if New Zealand does not take steps to smooth the tax rates through time, we could be faced with a marked increase (especially from 2021 to 2031) which might result in accelerated out migration. In fact, the international comparisons presented here, and notably those for Australia, suggest that this concern may not in fact be so serious. It appears to be that most other countries will face similar fiscal pressures. Of course over time their responses may differ, as some choose to sustain or expand current per capita expenditures, while in others some of the pressure may be relieved through reductions in benefit levels and eligibility. But concerns that New Zealand tax rates would have to move to rates significantly out of line with other OECD countries simply as a result of aging seem to be over played, based on current projections.

\section{Conclusions and Future Research}

The key points which emerge from this overview are as follows: Unquestionably major changes will occur as a result of an aging population. The ultimate outcomes will depend on behavioural responses, and the way policies institutions evolve. The projections lie well outside the range of historical experience, limiting the value for forecasting of studies based on existing data. Similar demographic changes phenomena are occurring in many countries it is the relative changes that will matter and globalisation will continue to be important in shaping outcomes. Aged dependency ratios in New Zealand are expected to rise in line with other OECD countries, although it may take up to another 40 years before total dependency ratios reach their levels of 1961. Household saving is expected to decline as more of the population moves into the retired aged group. Only limited empirical estimates are available of the magnitude of this decline, and the evidence is mixed for New Zealand. Investment needs can be expected to decline in line with the falling labour force, and the rate of economic growth may slow. The implications for the current account balance depend on not only on the relative movements in the desired level of saving and investment domestically, but also upon global capital flows. Global capital markets can play an important role in the intergenerational allocation of capital. 
This paper has constructed some scenarios by applying historical patterns of behaviour to projected economic trends. This approach, rightly labelled as "mechanistic" by Heller and Symansky (Heller and Symansky, 1997), is merely intended to provide a base line as to what might happen given projected demographic changes alone. It is useful for separating out the pressures that are expected to arise from the changing age structure, and is not intended as a forecast of the future time path of key economic and social variables. Asset prices and interest rates, technological possibilities, the demand for skills of different mixes, changing patterns of consumption and leisure are just some of the forces that will shape the future. Institutions will evolve to take advantage of new opportunities and changed relative prices.

Mechanistic projections, which fail to incorporate these behavioural responses, will run the same risk as the projections of the Club of Rome. Future research must constantly seek to refine the behavioural responses to changes in population aging.

While saving is a key behavioural variable that will doubtless be influenced by shifts in the age distribution, our knowledge of the relation between saving and the dependency rates is very sketchy. This is particularly true for New Zealand, where reliable estimates of current saving rates either in aggregate or at the household level are in short supply. A better understanding of the age related saving profile of households is essential, both as a basis for building a clearer picture of future macroeconomic changes, and to assess the adequacy of saving for retirement. The latter will be significantly helped by the results of the forthcoming Household Saving Survey being conducted by Statistics New Zealand.

\section{Notes}

1 DISCLAIMER: The views expressed are those of the author and do not necessarily reflect the views of the New Zealand Treasury. The Treasury takes no responsibility for any errors or omissions in, or for the correctness of, the information contained in this paper.

2 The adjustment factors and are 0.72,1.00 and 1.27 for the three aged groups young, working and old, respectively Cutler, D.M. Poterba, J. M., Sheiner, L. m. and Summers, L: 1990. An aging Society: Opportunity or Challenge? Brookings Papers on Economic activity 1190, 1-73.

3 There is an extensive literature in this area. The interested reader is referred to Leibfritz, W., Roseveare, D., Fore, D. and Wurzel, E.: 1995. Aging Populations, Pension Systems and Government Budgets: How do they Affect Saving? In Organisation for Economic Cooperation and Development, Paris. Disney, J. and Krever, R. (eds) (1996) Superannuation. Savings and Taxation.
Canberra: Centre for International and Public Law, ANU and the Taxation Law and Policy Research Unit, Deakin University. Disney, R (1996) Aging and Saving. Fiscal Studies 17:2, 83-101. Elmendorf, D. W. and Sheiner, L. M (1999) Should America Save for its Old Age? Population Aging, National Saving and Fiscal Policy. In Federal Reserve Board, Washington DC. Kohl, R. and O'Brien, P (1998). The Macroeconomics of Aging, Pensions and Savings: A Survey. In Organisation for Economic Cooperation and Development, Paris. Weil, D. N.: 1997. 'The Economics of Population Aging', in M. R. Rosenzweig and O. Stark, (eds.), Handbook of Population and Family Economics, Vol. 1B, Elsevier, Amsterdam, pp. 967-1014.,).

4 Note that it is the relative change in these shares not their absolute levels that are germane to this analysis. Clearly, the expenditure for health education and welfare is meet from all sources of tax revenue and not borne exclusively by the income of the working age population.

\section{References}

Bosworth, B. P. Burtless, G. and Sabelhaus, J. (1991) The Decline in Saving: Evidence from Household Surveys. Brookings papers on economic activity 1, 183-256.

Choy, W. K. (2000) The Determinants of New Zealand National and Household Saving Rates: A Cointegration Approach. The Treasury, Wellington.

Cutler, D. M. Poterba, J. M. Sheiner, L. M. and Summers, L. (1990) An Agining Society: Opportunity or Challenge? Brookings Papers on Economic Activity 1190, 1-73.

Disney, J. and Krever, R. (eds) (1996) Superannuation. Savings and Taxation. Canberra: Centre for International and Public Law, ANU and the Taxation Law and Policy Research Unit, Deakin University.

Disney, R. (1996) Aging and Saving. Fiscal Studies 17:2, 83-101.

Elmendorf, D. W. and Sheiner, L. M. (1999) Should America Save for its Old Age? Population Aging, National Saving and Fiscal Policy. Federal Reserve Board, Washington DC.

Guest, R. S. and McDonald, I. M. (2000) Population Aging and Projections of Government Social Outlays in Australia. Australian Economic Review $33,49-64$.

Heller, P. S. and Symansky, S. (1997) Implications for Savings of Aging Asian Tigers. International Monetary Fund, Washington., Washington DC. 
Higgins, M. (1998) Demography, National Savings, and International Capital Flows. International Economic Review 39, 343-369.

Higgins, M. and Williamson, J. G (1966) Asian Demography and Foreign Capital Dependence. National Bureau of Economic Research. Cambridge MA.

Kohl, R. and O'Brien, P (1998) The Macroeconomics of Aging, Pensions and Savings: A Survey. Organisation for Economic Cooperation and Development, Paris.

Leibfritz, W., Roseveare, D. Fore, D. and Wurzel, E. (1995) Aging Populations, Pension Systems and Government Budgets: How do they Affect Saving? Organisation for Economic Cooperation and Development, Paris.

Miles, D. (1999) Modelling the Impact of Demographic Change Upon the Economy. Economic Journal 109, 1-36.

OECD (1988) Aging populations: The Social Implications. Organisation for Economic Cooperation and Development, Paris.

Statistics New Zealand (2000) New Zealand Population Projections. Statistics New Zealand, Wellington.

Weil, D. N. (1994) The Saving of the Elderly in Micro and Macro Data. Quarterly Journal of Economics 109, 55-82.

Weil, D. N (1997) The Economics of Population Aging. Rosenzweig, M. R. and Stark,O. (eds.) Handbook of Population and Family Economics 1B, 967-1014. Elsevier, Amsterdam.

\author{
Author \\ Grant Scobie \\ Advisor \\ Policy Coordination and Development Section \\ The Treasury \\ P O Box 3724 \\ Wellington \\ Grant.Scobie@Treasury.govt.nz
}

